\title{
EFEKTIVITAS ZOOM CLOUD MEETING SEBAGAI MEDIA PEMBELAJARAN BAHASA ARAB ONLINE DI UIN SUNAN AMPEL SURABAYA
}

\author{
Rakhmaddiniah Sulistyawati' ${ }^{1}$, Danial Hilmi' ${ }^{2}$ \\ 1Pascasarjana UIN Maulana Malik Ibrahim Malang, Indonesia \\ 2Pascasarjana UIN Maulana Malik Ibrahim Malang, Indonesia \\ Email: rakhmaddiniah@gmail.com ${ }^{1}$, hilmi@pba.uin-malang.ac.id ${ }^{2}$
}

\begin{tabular}{c|c|c}
\hline Received: Desember 2021 & Accepted: Desember 2021 & Published: Januari 2022 \\
\hline
\end{tabular}

\begin{abstract}
This study aims to describe the effectiveness of using the Zoom Cloud Meeting application in online lectures for S1 PBA students at UIN Sunan Ampel Surabaya. The research seeks to present data on student recognition regarding their experiences during the distance lecture process by using the Zoom application. There are three main points to be explored, namely familiarity, deliverability and student assessment of the use of zoom as a learning medium. The study used qualitative research methods, where primary data was obtained through online interviews with 30 students. The results of the study concluded that the majority of students felt they were used to using zoom meetings and they could still receive learning well. The majority of students assessed that the main obstacle was the availability of a good network signal. Although there are shortcomings, it can still be concluded that the use of zoom meetings as a learning medium is quite effective, where students can still receive learning well, and learning objectives can be achieved.
\end{abstract}

Keywords: online lectures, Zoom Cloud Meeting, Arabic learning

\begin{abstract}
Abstrak: Penelitian ini bertujuan untuk mendeskripsikan efektivitas penggunaan aplikasi Zoom Cloud Meeting dalam perkuliahan daring mahasiswa S1 PBA UIN Sunan Ampel Surabaya. Penelitian berupaya menghadirkan data pengakuan para mahasiswa terkait pengalaman mereka selama mengikuti proses perkuliahan jarak jauh dengan pemanfaatan aplikasi Zoom tersebut. Terdapat tiga poin utama yang ingin digali, yaitu familiaritas, ketersampaian dan penilaian mahasiswa atas pemanfaatan zoom sebagai media pembelajaran. Penelitian menggunakan metode penelitian kualitatif, di mana data primer didapatkan melalui wawancara secara online kepada 30 mahasiswa. Hasil penelitian mendapatkan kesimpulan bahwa mayoritas mahasiswa merasa telah terbiasa menggunakan zoom meeting dan pembelajaran tetap dapat mereka terima dengan baik. Mayoritas mahasiswa menilai kendala utama adalah ketersediaan sinyal jaringan yang baik. Meski terdapat kekurangan, tetap dapat disimpulkan bahwa penggunaan zoom meeting sebagai media pembelajaran cukup efektif, di mana mahasiswa tetap dapat menerima pembelajaran dengan baik, dan tujuan pembelajaran dapat tercapai.
\end{abstract}

Kata Kunci: perkuliahan daring; Zoom Cloud Meeting, pembelajaran bahasa Arab 


\section{A. Pendahuluan}

Covid-19 yang belum menemui ujung sampai saat ini berimbas sangat terhadap pendidikan. Sehingga pemerintah dengan kewenangannya menerapkan kebijakan yakni menutup kegiatan pengajaran tatap muka dan mengubahnya menjadi sistem online atau daring. Dengan penyampaian materi secara online atau daring mahasiswa masih tetap dapat beraktivitas (perkuliahan, konsultasi, atau bimbingan) dengan dosen kapan saja. Sebaliknya, dosen pun masih bisa beraktifitas transfer keilmuannya kepada seluruh mahasiswanya. Artinya, secara teknis tidak ada yang berkurang dengan kegiatan ini.

Perkuliahan jarak jauh atau pembelajaran daring yang juga disebut dengan e-learning merupakan aplikasi yang sengaja dirancang guna menyelesaikan masalah keterbatasan antara guru-murid atau dosen-mahasiswanya terutama dalam hal ruang dan waktu. Melalui pembelajaran online tersebut, guru-murid atau dosen-mahasiswa tidak mesti ada di satu tempat yang sama. Metode perkuliahan daring atau jarak jauh bisa diterapkan pada empat aspek pendidikan, antara lain: "pendidikan umum, memperluas wawasan pendidik terhadap mapel atau mata kuliah yang diampukan, penguasaan pedagogi dan perkembangan anak, serta sebagai acuan atau panduan menuju kelas yang lebih baik."1

Di sisi yang lain, kuliah online juga menjadikan baik dosen dan mahasiswa lebih melek dan ramah teknologi. Secara praktik, kegiatan perkuliahan tidak terlalu berbeda dibanding tatap muka langsung, hanya saja dengan memanfaatkan teknologi. Kegiatan diskusi dan presentasi dilakukan dengan telekonferensi atau video conference. Sehingga, dengan begitu proses perkuliahan masih bisa dilaksanakan secara normal bahkan bisa diakses dimanapun dan kapanpun sebagaimana yang telah disepakati. Pemanfaatan video conference memiliki peran yang sangat baik, terlebih jika dilakukan secara tepat. ${ }^{2}$

Melalui video conferencing, perkuliahan melalui konferensi video menjadikan proses perkuliahan tatap muka tetap terlaksana sebagaimana biasanya. Kehadiran video conference menjadi solusi proses perkuliahan yang tidak bisa dilakukan sebagaimana normalnya, dengan video conference pendidik atau dosen masih akan bisa berinteraksi dengan peserta didik atau mahasiswa secara langsung. ${ }^{3}$ Selanjutnya media perkuliahan online atau daring alias berbasis internet tentunya wajib dengan penuh pertimbangan karena akan berbanding terbalik manakala tidak ada langkah

1 Firman Firman dan Sari Rahayu, "Pembelajaran online di tengah pandemi covid-19," Indonesian Journal of Educational Science (IJES) 2, no. 2 (2020): 82.

2 Sulis Sandiwarno, "Perancangan Model E-Learning Berbasis Collaborative Video Conference Learning Guna Mendapatkan Hasil Pembelajaran yang Efektif dan Efisien,” Jurnal Ilmiah FIFO 8, no. 2 (2016): 191.

3 Sandiwarno, 191. 
preventif terkait hal-hal negatif yang akan muncul dengan diterapkannya perkuliahan online itu sendiri. Sebagaimana mestinya bahwa seorang pengajar terlebih pendidik wajib memahami prinsip dan faktor yang bisa mempengaruhi efektivitas teknologi digital dalam proses pembelajaran. ${ }^{4}$

Konferensi video adalah pembelajaran yang tersinkronisasi. Synchronous learning adalah bersifat real time yang mana juga tetap dapat memungkinkan guru-murid atau dosen-mahasiswa berinteraksi satu sama lain pada waktu yang sama walau di jarak dan tempat yang berbeda. ${ }^{5}$ Dalam sebuah penelitian yang dilakukan oleh Denissa Alfiany Luhulima tahun 2016 menunjukkan bahwa pemanfaatan media pembelajaran video sangat membantu dalam proses pembelajaran formal dan nonformal. Anak generasi Z lahir di era teknologi tinggi, sehingga terbiasa dalam pembelajaran Metode dan media pembelajaran sangat umum dan intuitif. ${ }^{6}$

Zoom Cloud Meeting adalah aplikasi yang mampu memfasilitasi interaksi virtual antara dosen dan mahasiswa meskipun tidak bisa seratus persen terwakili karena bagaimanapun online adalah tidak sama dengan tatap muka riil (real meeting). Selanjutnya, terkait dengan sampel penelitian yang peneliti ambil adalah di UIN Sunan Ampel karena dari informasi yang didapat bahwa selama pandemi Covid-19 ini perkuliahan tetap dilakukan namun secara online. Lebih dari itu, proses perkuliahan didominasi penggunaan aplikasi Zoom Cloud Meeting. Dari situ peneliti tertarik mengkaji lebih jauh seperti apa efektivitas perkuliahan online tersebut karena peneliti merasa bahwa tentunya ada hal-hal yang berbeda bahkan minus jika dibandingkan dengan proses perkuliahan normal, hadir secara fisik. Tentunya tidak lepas dari kendala-kendala khususnya hal teknis.

Kemudian, pada bahasa Arab proses perkuliahan tidaklah sepenuhnya sesuai harapan dan tidak semua MK bisa tersampaikan sesuai tarjet. Dan ini adalah pengakuan riil yang didapati peneliti di lapangan artinya hal ini cukup mewakili atas dilakukannya penelitian ini. Realita perkuliahan online sebenarnya juga dilakukan di sejumlah institusi atau lembaga pendidikan lainnya. Namun, yang menjadi dasar atau urgensi penelitian disini adalah seperti apa respon mahasiswa terhadap perkuliahan online materi kuliah Bahasa Arab dilakukan. Apakah suda cukup representatif sehingga bisa dikatakan efektif. Kemudian seperti apa kendala-kendala dalam penyampaian materi perkuliahan, dan seperti apa pula solusinya sehingga materi tetap tersampaikan dengan baik. Sehingga ukuran efektifnya penggunaan aplikasi Zoom ini akan tetap

\footnotetext{
${ }^{4}$ Susilahudin Putrawangsa dan Uswatun Hasanah, "Integrasi teknologi digital dalam pembelajaran di era industri 4.0," Jurnal Tatsqif 16, no. 1 (2018): 42-54.

5 Nian-Shing Chen dkk., "A model for synchronous learning using the Internet," Innovations in Education and Teaching International 42, no. 2 (2005): 181-94.

${ }^{6}$ Hartati Lambuan dan Mariana AN Letuna, "Penggunaan Whatsapp sebagai Media Komunikasi Pacaran Jarak Jauh," Jurnal Communio: Jurnal Jurusan Ilmu Komunikasi 8, no. 2 (2019): 1362-91.
} 
peneliti sampaikan beriringan dengan kendala yang didapatinya. Mungkin hal ini semacam review akan tetapi disini lebih detail dan saintifik karena pengolahan data penelitian peneliti sampaikan dengan teori dan pendekatan metodologi.

Akhirnya, tujuan dari penelitian ini adalah untuk mengetahui keefektivitasan pembelajaran berbasis video conference melalui aplikasi Zoom Cloud Meeting sebagai media pembelajaran online pada mahasiswa S1 PBA UIN Sunan Ampel Surabaya saat pandemi Covid-19. Kebetulan di tahun akademik 2020/2021 semester gasal-genap ini, seluruh proses perkuliahan dilakukan secara daring atau online. Sehingga hal itulah yang mendorong peneliti untuk melakukan survey atau penelitian sederhana ini. Peneliti ingin mendapatkan data riil dari pernyataan mahasiswa sebagai pengguna Hasil penelitian diharapkan dapat menginspirasi para pendidik tidak hanya di institusi tingkat universitas namun semua tingkat selama memungkinkan bisa diterapkannya perkuliahan atau pembelajaran jarak jauh di saat pandemi Covid-19 ini.

\section{B. Metode Penelitian}

Penelitian ini menerapkan pendekatan kualitatif deskriptif. Tujuannya adalah mengungkap keefektivan penggunaan Aplikasi Zoom Cloud Meeting pada perkuliahan Bahasa Arab. Pendekatan kualitatif digunakan untuk menguak secara detail pengakuan responden terkait perkuliahan online yang menggunakan aplikasi Zoom Cloud Meeting. Melalui pendekatan kualitatif, peneliti menghadirkan jawaban-jawaban responden dengan melakukan pengerucutan asumsi-asumsi yang muncul. Hal ini menandakan bahwa metode kualitatif digunakan untuk menjawab pertanyaan tentang "apa (what)", "bagaimana (how)", atau "mengapa (why). Dengan metode gabungan tersebut peneliti berusaha mendeskripsikan atas jawaban para responden tentang pemanfaatan aplikasi zoom dalam proses dan aktivitas pembelajaran atau perkuliahan mereka.

Tentang pertanyaan yang diajukan oleh peneliti adalah bersifat statement answer sehingga jawaban responden adalah bersifat subyektif namun tetap obyektif. Adapun pertanyaan yang peneliti ajukan kepada responden adalah sebagai berikut. (1) Apakah selama pandemi ini perkuliahan dilakukan secara daring / online? dan apakah selama ini sering menggunakan aplikasi zoom? jika iya, mohon berikan klarifikasinya. (2) Bagaimana menurut kalian pemahaman materi dengan menggunakan aplikasi zoom? Apakah cukup memadai? Kalau iya bagaimana? Kalau tidak bagaimana? Tolong berikan pendapat kalian. (3) Apa pendapat kalian tentang keunggulan dan kelemahan zoom.

Dari tiga pertanyaan tersebut peneliti berusaha menghadirkan jawaban yang masing-masing mengerucut pada tiga hal pula. Pertanyaan pertama mengarah pada familiarity (kebiasaan); 
pertanyaan kedua mengarah pada ketersampaian; dan pertanyaan ketiga mengarah pada penilaian. Adapun tiga poin tersebut adalah dimaksudkan sebagaimana berikut. (1) Familiarity (Kebiasaan/Mengenal) atau familer yakni akrab,7 (dalam hal ini terbiasa dengan zoom) adalah pengakuan responden tentang aplikasi zoom dan kebiasaan mereka saat menggunakan aplikasi tersebut pada proses perkuliahan. (2) Ketersampaian, artinya ulasan materi yang disampaikan oleh dosen saat perkuliahan dengan memanfaatkan aplikasi zoom apakah dapat diterima dengan baik oleh mahasiswa. (3) Penilaian, yakni responden berdasarkan pengalamannya mengutarakan pendapatnya atas plus-minus atau kelebihan-kekurangan aplikasi zoom dalam perkuliahan online.

Selanjutnya, dengan model pengelompokan data yang seperti itu, sampel dari penelitian ini adalah mahasiswa S1 PBA UIN Sunan Ampel Surabaya dari beberapa angkatan 2018 sampai 2020 yang mana peneliti ambil secara random dan mahasiswa tersebut tentunya tercatat sebagai mahasiswa aktif dan mengikuti perkuliahan daring selama dua semester berlangsung. Sampel dari penelitian ini yakni sebanyak 30 mahasiswa yang telah memberikan keterangan atau diwawancarai menggunakan aplikasi Whatsapps.

Objek penelitian ini adalah hasil belajar atau perkuliahan mahasiswa. Teknik pengumpulan data yang dilakukan adalah berupa memberikan pertanyaan dan atau wawancara khusus secara online melalui chat whatsapp mengingat masih situasi pandemi belum memungkinkan secara bebas melakukan wawancara dan mendapatkan jawaban secara langsung tatap muka. Dengan direkamnya jawaban atau keterangan responden melalui WA maka didapatkanlah beragam data dan informasi yang dibutuhkan, selanjutnya peneliti melakukan analisa data. Dalam proses penganalisaan data, peneliti melakukan pemilahan transkrip hasil rekaman dengan responden. Semua kata-kata responden ditulis kemudian dikelompokkan sesuai dengan kebutuhan atas tiga poin besar yang sudah dijelaskan diatas (Familiarity, Ketersampaian, dan Penilaian). Proses pengelompokkan data mentah tersebut adalah bagian dari analisa data yang disebut dengan reduksi. Analisa data dilakukan dengan menerapkan pola bahwa peneliti mereduksi data-data yang sudah didapatkan tadi, kemudian penyajian data dan dilakukan penarikan kesimpulan. Hal ini sejalan dengan teknik analisis data dari Miles, Huberman \& Saldana. ${ }^{8}$

Dalam proses reduksi data tersebut diakhiri dengan pendeskripsian data melalui pengasumsian dan pengembangan teori. Dituangkannya data dengan bahasa tulis untuk penyajian data secara detail dan dilakukan Penyajian data tersebut merupakan bagian penting bagaimana

7 KBBI, “Arti kata familier - Kamus Besar Bahasa Indonesia (KBBI) Online,” diakses 2 Januari 2022, https://kbbi.web.id/familier.

${ }^{8}$ Matthew B. Miles, A. Michael Huberman, dan Johnny Saldaña, Qualitative Data Analysis: A Methods Sourcebook, 3 ed. (United States of America: Sage Publications, Inc, 2014). 
peneliti menghadirkan proses penelitian dalam memperoleh jawaban atas efektivitas perkuliahan online yang dilakukan oleh dosen dengan mahasiswa S1 PBA UIN Sunan Ampel Surabaya di masa pandemi Covid-19 ini. Adapun yang dimaksud perkuliahan online dalam penelitian ini adalah perkuliahan dengan memanfaatkan aplikasi Zoom Cloud Meeting.

\section{Hasil dan Pembahasan}

\section{Efektifitas Penggunaan Zoom Cloud Meet Dalam Pembelajaran Daring}

Pembelajaran daring pada dasarnya memberi ruang yang tidak terbatas dengan jangkauan jarak yang berjauhan dengan melibatkan aplikasi tertentu sebagai perangkat yang menghubungkan antara pendidik dan peserta didik. Untuk menjalankannya diperlukan aplikasi khusus yang mempertemukannya. Salah satu aplikasi yang digunakan dalam penelitian ini adalah penggunaan Zoom Cloud Meet yang menjadi perbincangan hangat sejak era pandemi covid-19 yang menuntut belajar secara cepat tanpa interaksi langsung.

Pembelajaran daring pada dasarnya memberi ruang yang tidak terbatas dengan jangkauan jarak yang berjauhan dengan melibatkan aplikasi tertentu sebagai perangkat yang menghubungkan antar pendidik dan peserta didik. Untuk menjalankannya diperlukan aplikasi khusus yang mempertemukannya. Salah satu aplikasi yang digunakan dalam penelitian ini adalah penggunaan Zoom Cloud Meet yang menjadi perbincangan hangat sejak era pandemi covid-19 yang menuntut belajar secara cepat tanpa interaksi langsung.

Situasi seperti ini menuntut pendidik untuk lebih kreatif dalam memilih dan merancang pembelajaran yang inovatif dengan mengedepankan efektifitas pembelajaran yang dalam hal ini adalah proses pembelajaran bahasa Arab yang dapat membantu optimalisasi belajar yang optimal. Dalam pada itu, pembelajaran bahasa Arab yang dilakukan secara online atau daring akan sedikit mengurangi nilai tatap muka yang selama ini menjadi tren dalam pembelajaran konvensional.

Hasil penelitian ini diperoleh dari 30 responden yang berasal dari mahasiswa PBA S1 UIN Sunan Ampel Tahun Akademik 2020/2021 yang masih aktif mengikuti perkuliahan secara online. Peneliti merangkum jawaban atau penjelasan responden atas pertanyaan yang diajukan menjadi tiga poin yang sebagaimana dijelaskan di metode penelitian di atas antara lain Familiarity (Kebiasaan/Mengenal), Ketersampaian, dan Penilaian. Adapun data yang berhasil terhimpun dapat dilihat melalui grafik sebagaimana gambar 1 . 


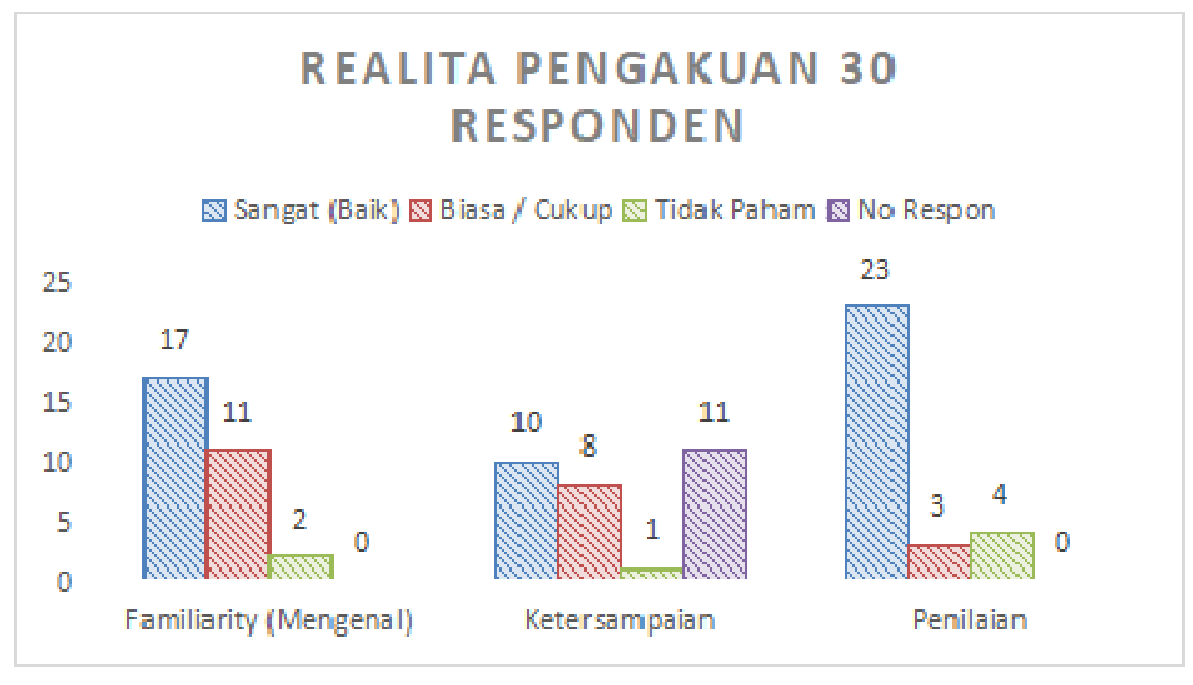

Gambar 1. Sebaran Pengakuan

Gambar 1 menunjukkan bahwa dari 30 orang responden menunjukkan bahwa dalam menjawab pertanyaan yang berhubungan dengan poin pertama familiarity (mengenal) ada 28 orang yang mengenal Zoom yakni 17 orang sangat mengenal dengan baik dan 11 orang cukup atau biasa saja. Sedangkan yang 2 lainnya mengaku tidak terlalu mengenal dikarenakan perkuliahan jarang menggunakannya. Dari pengakuan para responden tersebut ditemukan jawaban bahwa Zoom Meeting sudah cukup masyhur dan mayoritas telah pernah mempraktekkannya dalam situasi perkuliahan.

Berikutnya, untuk yang terkait dengan poin kedua ketersampaian terdapat 18 mengaku bahwa proses perkuliahan dengan zoom sangatlah bisa dimengerti. Sedangkan 1 orang menyatakan tidak efektif. Lalu 11 lainnya tidak memberikan keterangan detail. Sehingga jika dilihat dari jumlah 18 pengakuan yang menyatakan bahwa melalui Zoom materi perkuliahan tersampaikan dengan baik maka hal ini masih bisa dikatakan baik karena meskipun bagi 11 orang atau responden yang tidak merespon terkait hal ini, mereka tetap menyampaikan poin penilaian yang teruraikan dibawah ini.

Ada 26 responden yang mengemukakan poin penilaian. Semua diantara mereka menyatakan bahwa Zoom memiliki keunggulan antara lain fiturnya lebih bagus dan beragam, bisa memuat peserta banyak sampai 1000 orang, bisa share screen, dan bisa direkam kegiatan perkuliahannya tersebut sehingga pasca perkuliahan masih bisa diputar kembali bagi user yang ingin mengulang atau hendak mendapatkan penjelasan kembali. Sedangkan, 4 responden yang tidak memberikan keterangannya adalah dikarenakan 2 diantaranya tidak terlalu mengenal Zoom, 1 responden tidak 
memiliki device yang support sehingga selama ini hanya via record WhatsApp atau yang lainnya, dan 1 responden terakhir tidak memberikan keterangan lebih.

Selain dari pemetaan jawaban dan uraian-uraian atas sebaran pengakuan responden diatas, peneliti menemukan jawaban bahwa mayoritas (23) responden memberikan pengakuan atas keunggulan Aplikasi Zoom, dan mereka betul-betul mengalami adanya manfaat dengan menggunakannya dibanding aplikasi yang lain. Beberapa diantara mereka bahkan membandingkan dengan Aplikasi G-Classroom dan G-Meet yang dirasa masih belum sebagus Zoom Cloud Meeting. Oleh karena itu, peneliti berani memastikan dan menyimpulkan bahwa Zoom masih sangat representatif untuk proses perkuliahan online dibanding aplikasi lain.

Selanjutnya, peneliti juga berhasil mendapatkan jawaban-jawaban tambahan terkait dengan penilaian yang perlu dijadikan pertimbangkan oleh para user dari aplikasi Zoom. Dari sekian responden mayoritas juga menemukan kendala teknis sebagaimana berikut. Dari pernyataan 30 responden yang ada, 16 responden mengakui kelemahan atau kendala terbesar adalah jaringan internet. Mereka juga ada yang menyatakan bahwa Zoom menyaratkan jaringan yang kuat, tidak bisa hanya sekedar ada. Jika sinyal tidak kuat maka Zoom akan terganggu seperti alan leave sendiri, tampilan menghitam dan suara tidak jelas. Kemudian, jika lebih dari 40 menit akan disyaratkan untuk yang premium sehingga ketika lebih dari 40 menit dengan sendirinya user akan leave dan tidak lagi join di meeting virtual tersebut, harus klik log in dan menunggu dikonfirmasi oleh admin. Hal ini sangat perlu diperhatikan. Karena dibalik keunggulan yang dimiliki Aplikasi Zoom, ternyata memang ada konsekuensi yang harus diterima oleh user. Tetapi hal ini wajar, peneliti kira "ketersediaan jaringan" adalah mutlak perlu, tidak hanya untuk aplikasi Zoom Cloud tetapi untuk semua.

Kembali pada pembahasan efektifitas pembelajaran online yang diberlakukan di PBA UIN Sunan Ampel Surabaya tersebut maka peneliti menyimpulkan bahwa mahasiswa lebih fleksibel saat melaksanakan perkuliahan. Mayoritas mengakui telah familier dengan Zoom dan merasa pembelajaran tetap dapat sampai dan mereka terima dengan baik. Dengan demikian dapat dikatakan bahwa penggunaan zoom cukup efektif untuk kegiatan pembelajaran bahasa Arab.

Dengan pengakuan para responden yang semuanya adalah mahasiswa aktif dan menjalani proses perkuliahan secara daring tersebut didapatkan jawaban bagi mahasiswa perkuliahan jarak jauh, online memiliki tantangan tersendiri. Tantangan ini bisa berupa ketersediaan layanan internet. Mahasiswa menyatakan bahwa memiliki kuota data yang lebih banyak itu adalah suatu keharusan. Karena mayoritas mahasiswa menggunakan fasilitas layanan data seluler perorangan 
(pribadi) untuk mengaksesnya. Pada saat yang sama, hanya sebagian kecil mahasiswa yang menggunakan WIFI.

\section{Penggunaan Zoom Cloud Meet Sebagai Sarana Distance learning}

Zoom Cloud Meet menjadi pembicaraan hangat sejak maret 2020 dimana pandemi Covid-19 berkecamuk dalam berbagai lini kesehatan dunia. Oleh karena itu, dunia pendidikan turut ambil bagian dalam menyelenggarakan pendidikan yang salah satunya memanfaatkan penggunaan Zoom Cloud Meet yang mampu menampung sekian banyak mahasiswa atau peserta dan dipandang memiliki fasilitas yang memadai untuk dilangsungkan proses pembelajaran bahasa Arab yang efektif.

Proses pembelajaran Bahasa Arab selama ini dengan menggunakan Zoom Cloud Meet cukup berhasil mengurangi dampak ketinggalan materi yang pernah diduga sebelumnya. Dalam beberapa penelitian juga penggalian data dapat dilakukan secara efektif baik itu untuk ujian lisan maupun tertulis. Lebih dari itu, setelah melakukan penggalian lebih detail melalui https://www.localstartupfest.id, peneliti mendapat informasi terkait beberapa keuntungan ketika mempergunakan aplikasi Zoom. Diantaranya :

a. Zoom dapat didownload dengan tanpa biaya yang bisa menampung hingga 1000 peserta.

b. Dapat menjadwalkan pembelajaran melalui fungsi perencanaan atau lewat fitur Schedule (penjadwalan).

c. Selama proses pembelajaran berlangsung video pembelajaran dapat direkam dan disimpan.

d. Zoom Cloud Meeting dapat berjalan di perangkat android, Ios, Windows, dan Mac Virtual Background yang dapat diganti.

Berdasarkan penjelasan tersebut maka dapat dikatakan bahwa dengan penggunaan aplikasi Zoom yang telah disiapkan ketika adanya pandemi covid-19 sekarang ini, pembelajaran online di UIN Sunan Ampel Surabaya sudah cukup efektif. Pembelajaran atau perkuliahan yang bisa dikatakan efektif dan penerapannya mempermudah mahasiswa dalam mengikuti kegiatan perkuliahan secara online/ jarak jauh. Hal ini ditemukan pula oleh peneliti bahwa perkuliahan dengan menggunakan aplikasi Zoom diterima dengan sangat baik oleh mahasiswa. Bervariasinya fitur - fitur yang dapat memberi kemudahan sehingga menjadi sisi lebih agar menjadikan proses pembelajaran secara online itu lebih mudah.

Terkait konsep atau teori yang relevan dengan temuan penelitian ini, peneliti mengaitkan dengan konsep distance learning atau distance education. Konsep atau teori ini ternyata telah lama 
ada dan pernah diterapkan. Distance learning adalah sistem dimana terdapat pemisahan antara pengajar dan siswa baik secara ruang dan/atau waktu. Distance learning dikembangkan pertama kali di Amerika Serikat, Perancis, Jerman, dan Inggris di pertengahan 1800-an. Pada tahun 1840, Sir Isac Pitman mengajar jarak jauh menggunakan surat. Dan pada tahun 1980an, International Correspondence Schools (ICS) mengembangkan metode perkuliahan "home-study courses" karena faktor keamananan pada saat itu. Berikut adalah gambar sederhana untuk memperjelas proses sejarah munculnya konsep pembelajaran jarak jauh. Menurut Horton dalam bukunya Designing Web Based-Training dijelaskan tentang sejarah berjalannya distance learning yang turut andil dalam meramu model pembelajaran daring sebagaimana gambar $2:^{9}$

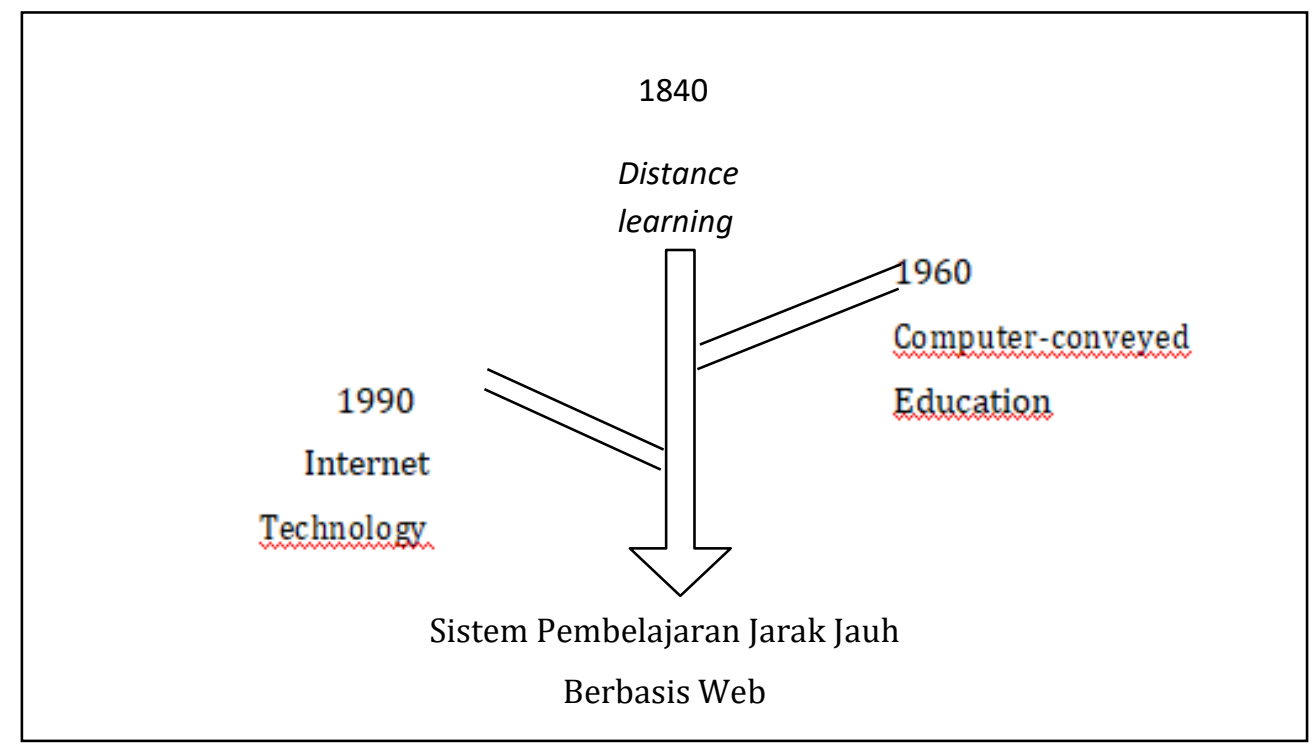

Gambar 2. Sejarah Distance learning

Dari sini dapat dikatakan bahwa pembelajaran atau perkuliahan jelas tidak akan ada masalah meskipun dilakukan dengan jarak jauh. Efektifitas didalamnya bergantung pada bagaimana penguasaan capaian teknologi dan penguasaan ini. Era dewasa ini, semakin berkembangnya penemuan teknologi dan aplikasi yang bisa digunakan dan dikembangkan untuk mendukung proses pembelajaran jarak jauh tentunya menjadi sangat aplikatif. Artinya, sepertinya Zoom Cloud Meeting adalah bagian dari perkembangan teknologi yang bisa diterapkan untuk pembelajaran jarak jauh yang tentunya jauh lebih baik dibanding era Distance learning di era 1840-an, Computer-Conveyed Education di era 1960-an, dan Internet Technology di era 1990-an.

9 William Kendall Horton, Designing web-based training: How to teach anyone anything anywhere anytime, vol. 1 (New York: Wiley New York, 2000), 134. 
Pemanfaatan Zoom Cloud Meet ini sejatinya berasal dari model Distance learning yang telah melalui berbagai metamorfosis sehingga tidak lagi proses dijalankan secara kuno berbasis penugasan, melainkan dapat dilakukan dengan tatap muka secara virtual. Hal ini menandakan bahwa penggunaan Zoom Cloud Meet ini mampu mengganti proses pembelajaran tatap muka dengan secara langsung berinteraksi dengan memanfaatkan fasilitas yang ada di dalamnya.

\section{Kesimpulan}

Pembelajaran secara online dengan menggunakan aplikasi zoom mendapat respon yang baik dari mahasiswa karena disaat pandemi seperti sekarang ini yang tidak memungkin tatap muka secara langsung satu lokasi sehingga daripada harus stuck dan berhentinya proses transfer keilmuan maka perkuliahan atau pembelajaran daring adalah solusi yang tepat. Pembelajaran online via zoom adalah dirasa efektif karena keunggulannya dibanding aplikasi-aplikasi lain. Meskipun juga memiliki kelemahan atau konsekuensi bagi para usernya. Setidaknya dengan adanya pembelajaran online via aplikasi Zoom Cloud Meeting menjadikan mahasiswa tetap aktif melaksanakan proses perkuliahan. Mereka lebih melek teknologi, mandiri dan menjadikan mahasiswa untuk lebih aktif dan kreatif dalam perkuliahan.

Di lain sisi, ada hal yang menjadi perhatian atau antisipasi praktik perkuliahan online menggunakan aplikasi zoom ini yakni ketersediaan jaringan internet yang baik. Artinya, ini adalah syarat mutlak yang harus ada. Kestabilan koneksi sangat berpengaruh terhadap kelancaran proses Video Conference, terputus sedikit saja, akan berimbas pada utuh dan tidaknya pemahaman mahasiswa pada materi yang disampaikan dosen. Kemudian antisipasi padam listrik dan support devices nya dengan aplikasi zoom tersebut karena zoom juga menyaratkan pada devices tertentu. Tidak semua device HP atau Laptop bisa untuk mengaktifkan aplikasi zoom. Meskipun demikian, pembelajaran online melalui Zoom masih menjadi pembelajaran online yang cukup efektif dan kreatif sebab kelengkapan fitur - fitur yang membantu ketika proses pembelajaran daring saat pandemic covid-19. Hal ini lah yang menjadikan aplikasi Zoom Cloud Meeting masih menjadi dominan dipakai pada proses perkuliahan dimanapun, khususnya pada mahasiswa PBA S1 UIN Sunan Ampel Surabaya

\section{Daftar Rujukan}

Chen, Nian-Shing, Hsiu-Chia Ko, Kinshuk, dan Taiyu Lin. (2005). "A model for synchronous learning using the Internet." Innovations in Education and Teaching International 42, no. 2: 181-94.

Firman, Firman, dan Sari Rahayu. (2020). "Pembelajaran online di tengah pandemi covid-19." Indonesian Journal of Educational Science (IJES) 2, no. 2: 81-89. 
Horton, William Kendall. (2000). Designing web-based training: How to teach anyone anything anywhere anytime. Vol. 1. New York: Wiley New York.

KBBI. “Arti kata familier - Kamus Besar Bahasa Indonesia (KBBI) Online.” Diakses 2 Januari 2022. https://kbbi.web.id/familier.

Lambuan, Hartati, dan Mariana AN Letuna. (2019). "Penggunaan Whatsapp sebagai Media Komunikasi Pacaran Jarak Jauh." Jurnal Communio: Jurnal Jurusan Ilmu Komunikasi 8, no. 2: 1362-91.

Miles, Matthew B., A. Michael Huberman, dan Johnny Saldaña. (2014). Qualitative Data Analysis: A Methods Sourcebook. 3 ed. United States of America: Sage Publications, Inc.

Putrawangsa, Susilahudin, dan Uswatun Hasanah. (2018). "Integrasi teknologi digital dalam pembelajaran di era industri 4.0." Jurnal Tatsqif 16, no. 1: 42-54.

Sandiwarno, Sulis. (2016). "Perancangan Model E-Learning Berbasis Collaborative Video Conference Learning Guna Mendapatkan Hasil Pembelajaran yang Efektif dan Efisien." Jurnal Ilmiah FIFO 8, no. 2: 191. 